\title{
Intrinsic and Extrinsic Motivation of Discipline Through the Role of Community Identification (Study on Covid-19 Activist Community in Tangerang)
}

\author{
HM Thamrin* \\ Universitas Muhammadiyah Tangerang \\ thamrinaroba@yahoo.com
}

\author{
Badawi \\ Universitas Muhammadiyah Cirebon \\ badawiawi@yahoo.co.id
}

\begin{abstract}
Discipline in carrying out Large-Scale Social Restrictions (PSBB) is a regulation including in the Acceleration of Handling the COVID-19. In reality, the implementation of PSBB is still not well understood by the community. The purpose of this study is to examine the influence of intrinsic motivation (a pleasure to help and hedonic value) and extrinsic motivation (reputation and reciprocity) on the discipline of the implementation of PSBB during COVID-19 pandemic. This study also examines the role of community identification on mediating the influence between intrinsic (a pleasure to help and hedonic value) and extrinsic (reputation and reciprocity) motivation toward the discipline of the implementation of PSBB during COVID-19 pandemic. This study uses quantitative research method by distributing a questionnaire to 120 respondents, which then analyzed using SEM method. This study shows that intrinsic motivation, such as pleasure to help and hedonic value, has an influence on community identification and discipline. Extrinsic motivation such as reputation and reciprocity also has an influence on community identification and discipline as well. The results of this study also show that community identification mediates the influence between intrinsic and extrinsic motivation on the discipline of the implementation of PSBB during COVID-19 pandemic.
\end{abstract}

Keywords: intrinsic motivation, extrinsic motivation, community identification, discipline of the implementation of PSBB during COVID-19

\section{INTRODUCTION}

With the implementation of the Large-Scale Social Restrictions (PSBB), there are many interesting phenomena, including the PSBB activists from students, netizens, and mass organizations in Indonesia. The activist community of COVID-19 created various new social spaces to help the government in educating the spread of the COVID-19 pandemic through posting information related to the implementation of PSBB in cyberspace, [1], [2]. The task of the activist community of COVID-19 is not limited to communicate the understanding of the PSBB. However, they also have a task to share the experience of people who have tested positive for COVID-19. The success of the activist community is clearly inseparable from the considerable number of active members who support and contribute voluntarily. However, there are a large number of members who only take the benefit for their interest from the dedication offered to others [3]. Individuals with this behavior tend to exert less effort when participating in community groups rather than working individually [4], and it is considered as social easing, which will hamper the development of the community.

The success of motivating the member of the activist community of the implementation of PSBB during COVID-19 pandemic depends on how the organization understands individual motives in the community. In this case, the activist community is not only expected to be capable and skilled but most importantly, they want to work hard and are willing to achieve maximum results [5]. The community member who has good work motivation can increase work productivity in accordance with specified goals. Therefore, the role of the leader becomes important in the organization to understand individual motives in the community in order to motivate members.

Intrinsic motivation is a behavior to involve one to provide satisfaction and pleasure. Intrinsic motivation has a non-instrumental nature, which means that actions that are intrinsically motivated do not depend on results that can be separated from the behavior itself [6]. The initial research on intrinsic motivation begins with research regarding how extrinsic rewards affect intrinsic motivation. The result of the study showed that if someone is involved freely in an activity (without interest) and is offered an external gift such as money [7] or point [8] for being involved in that activity, the intrinsic motivation will decrease. Intrinsic motivation illustrates the inherent tendency that individuals engage in activities because of interest, pleasure, and inner satisfaction [9], such as selfreward. It is also added that the result of the study shows that intrinsic motivation is the main trigger 
in explaining the contribution of individual knowledge [10]. Altruism shows people's pleasure in helping others without expecting anything in return [11].

Extrinsic motivation is defined as the result of behavior that is based on separate actions. Extrinsic motivation is instrumental and multidimensional and has variations from the external [6]. Extrinsic motivation is goal-oriented, which shows that the performance of an activity is based on cost-benefit analysis and is separated from individual involvement [12]. Reputation ad reciprocity is two of the most representative strength that provides knowledge contribution to community identification [13] Reciprocal relationship is considered as an exchange of a fair and beneficial action [14].

The lack of discipline in implementing PSBB becomes a serious problem that not only disrupts the performance of PSBB implementation both in quantity and quality [15] as well as content renewal, but it also interferes with interaction and cohesion between members [14]. There is even a tendency for increasing members which leads to the worst situation in which a member or individual wants to leave and no longer participate in the community. Noting the negative effect of the phenomenon, it is truly necessary to understand the inhibiting factors.

This study wants to examine explicitly about the influence of intrinsic motivation (a pleasure to help and hedonic value) and extrinsic motivation (reputation and reciprocity) on the discipline of the implementation of PSBB during COVID-19 pandemic. This study also examines the role of community identification on mediating the influence between intrinsic (a pleasure to help and hedonic value) and extrinsic (reputation and reciprocity) motivation toward the discipline of the implementation of PSBB during COVID-19 pandemic

\section{METHOD}

This method of this study is causality research which aims to analyse whether there is a mutual relationship between variables. This study is conducted at the COVID-19 Activist Community in Tangerang, Indonesia. The sampling technique of this study uses purposive sampling method, with the total number of 120 respondents. The distribution of the questionnaire in this study is by asking the members of the activist community regarding the discipline of the implementation of PSBB during the COVID-19 pandemic in Tangerang. All variables are measured using 6 points Likert scale, with 1 (strongly disagree) to 6 (strongly agree). There are five variables used in this study, including intrinsic motivation which consists of pleasure to help and hedonic value, developed by [16], an extrinsic motivation which consists of reputation and reciprocity, developed by [16], community identification of COVID-19 activist community, developed by[16], and discipline variable. The analysis technique used in this study is Structural Equation Modeling (SEM).

\section{RESULT \& DISCUSSION}

Based on the results of data processing, it can be known that the number of male respondents is 97 $(80.8 \%)$ and female respondents are $23(19.2 \%)$. Respondents with age of $15-20$ years old is 34 $(28.3 \%) ; 21--30$ years old is $45(37.5 \%), 31-40$ years old is $23(19.2 \%)$; 41 years old is $18(13.8 \%)$. Respondents with the education of junior high school are $19(15.8 \%)$; senior high school is 21 $(17 \%)$, bachelor degree is $75(62.5 \%)$, master degree is $4(3.3 \%)$, and doctoral degree is $1(0.8 \%)$. The number of respondents that have become the member of the activist community for $1-3$ years is 45 (37.5) 4-6 years is $57(47.5 \%)$, and > 7 years 18 $(15 \%)$. The Results of Structural Equation Modelling Intrinsic and Extrinsic Motivation, Community Identification, and Discipline in Figure 1.

Table 1. The Influence of Dependent and Independent Variable on Structural Mode

\begin{tabular}{|c|c|c|c|c|c|c|}
\hline \multicolumn{3}{|c|}{ Variable Influence } & Standardi & $\mathrm{CR}$ & $\mathrm{P}$ & Information \\
\hline $\begin{array}{l}\text { Community } \\
\text { Identification }\end{array}$ & $<-$ & $\begin{array}{l}\text { Pleasure to } \\
\text { help }\end{array}$ & -0.193 & -2.066 & 0.039 & Significant \\
\hline $\begin{array}{l}\text { Community } \\
\text { Identification }\end{array}$ & $<-$ & $\begin{array}{l}\text { Hedonic } \\
\text { Value }\end{array}$ & -0.304 & -3.128 & 0.002 & Significant \\
\hline $\begin{array}{l}\text { Community } \\
\text { Identification }\end{array}$ & $<-$ & Reputation & -0.241 & -2.581 & 0.010 & Significant \\
\hline $\begin{array}{l}\text { Community } \\
\text { Identification }\end{array}$ & $<-$ & Reciprocity & -0.260 & -2.820 & 0.005 & Significant \\
\hline $\begin{array}{l}\text { The discipline } \\
\text { of PSBB } \\
\text { Implementation }\end{array}$ & $<-$ & $\begin{array}{l}\text { Community } \\
\text { Identificatio } \\
\mathrm{n}\end{array}$ & -0.595 & -4.818 & 0.000 & Significant \\
\hline
\end{tabular}

Table 1 and Figure 1 explained that: (1) H1: Intrinsic motivation which consists of pleasure to help and hedonic value, has a negative significant influence on the community identification. The standardised path coefficient on the pleasure to help variable is -0.193 , and on the hedonic value is -0.304 . This finding shows that the greater the motivation to have pleasure to help and hedonic value, the greater the increase in community identification. Conversely, the lower the pleasure to help and the hedonic value, the smaller the community identification would be. (2) Extrinsic motivation which consists of reputation and reciprocity has a negative significant influence on community identification. The standardised path coefficient on the reputation variable is- 0.260 , and for the reciprocity variable is -0.260 . The result of this study indicates that the motive to get reputation and reciprocity can increase community identification. (3) H3: Community Identification has a negative significant influence on the discipline, with the path coefficient of -0.595 . 
Based on the results of indirect influence, the total influence for $\mathrm{H} 5$ can be seen on Table 2 below.

Table 2 .Indirect Effect and Total Effect

\begin{tabular}{|c|c|c|c|c|c|}
\hline $\begin{array}{l}\text { Independent } \\
\text { Variable }\end{array}$ & $\begin{array}{l}\text { Mediation } \\
\text { Variable }\end{array}$ & Dependent Variable & $\begin{array}{l}\text { Indirect } \\
\text { Effect }\end{array}$ & $\begin{array}{l}\text { Total } \\
\text { effect }\end{array}$ & $\begin{array}{c}\text { P- } \\
\text { Value }\end{array}$ \\
\hline $\begin{array}{l}\text { Pleasure to } \\
\text { help }\end{array}$ & $\begin{array}{l}\text { Community } \\
\text { identification }\end{array}$ & $\begin{array}{l}\text { Discipline of PSBB } \\
\text { Implementation }\end{array}$ & $-0,133$ & -0.193 & 0,000 \\
\hline Hedonic Value & $\begin{array}{l}\text { Community } \\
\text { identification }\end{array}$ & $\begin{array}{l}\text { The discipline of PSBB } \\
\text { Implementation }\end{array}$ & -0.210 & -0.304 & 0,000 \\
\hline Reputation & $\begin{array}{l}\text { Community } \\
\text { identification }\end{array}$ & $\begin{array}{l}\text { The discipline of PSBB } \\
\text { Implementation }\end{array}$ & -0.166 & -0.241 & 0,000 \\
\hline Reciprocity & $\begin{array}{l}\text { Community } \\
\text { identification }\end{array}$ & $\begin{array}{l}\text { The discipline of PSBB } \\
\text { Implementation }\end{array}$ & -0.179 & -0.260 & 0,000 \\
\hline
\end{tabular}

It can be seen in Table 2 and Figure 1 that community identification mediates the influence between pleasure to help and hedonic value on the discipline of PSBB implementation with the significance value of 0.000 . Community identification mediates the influence of reputation and reciprocity on the discipline of PSBB implementation.

The finding of the discipline of the PSBB implementation is shown in Figure 1 and Table 1 that are reflected from both intrinsic and extrinsic motivation. The main contribution of this study is the dynamics of social problems in the activist community of PSBB in Tangerang. In general, this result shows that intrinsic motivation which consists of pleasure to help and hedonic value, has a negative influence on community identification. This means that the greater the motivation to have a pleasure to help, the smaller the community identification would be. This finding provides meaning that individuals who have the pleasure to help and have hedonic values have a better inherent identity because it does not prioritise the identity of the community. This finding is developed from the previous studies, Chang et al. [16] stated that intrinsic motivation in the form of pleasure to help and hedonic value can increase the identity of an online community. However, this finding contradicts the research conducted by Yoo \& Gretzel [17], which stated that the member of the community generate contributions with hedonic orientation and always search more through an online platform.

This study also found that extrinsic motivation which consists of reputation and reciprocity, can increase community identification of the PSBB activist community. This finding reflects that there is connectivity between motivation to have

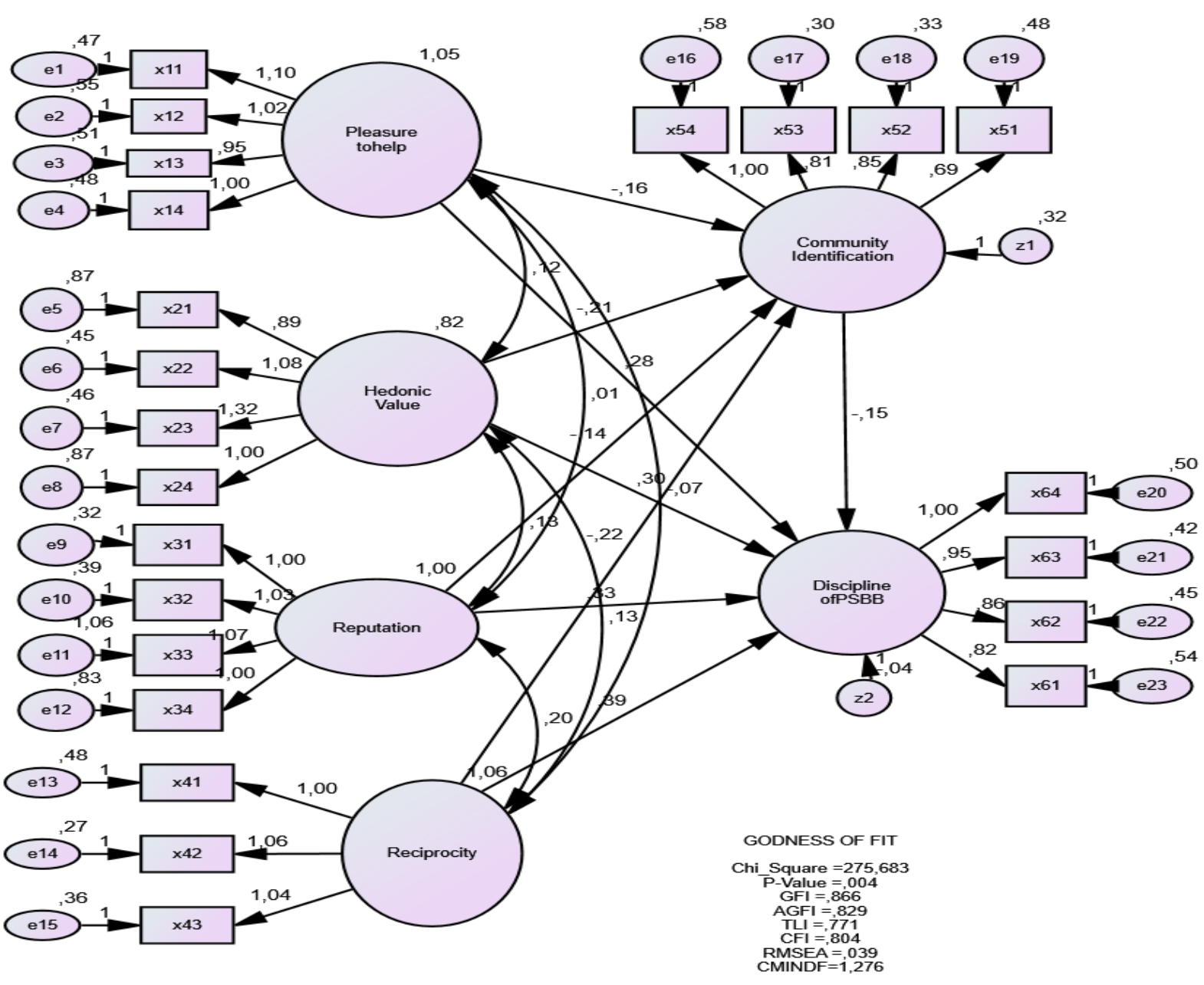

Figure 1.The Results of Structural Equation Modelling Intrinsic and Extrinsic Motivation, Community Identification, and Discipline 
reputation and reciprocity to find pleasure from through the contribution of collective activity. This finding contradicts with the research conducted by [18], which showed that reputation and reciprocity are not related to behavior $\mathrm{s}$ that contribute significantly. It is also not in accordance with the conclusion drawn by Wang \& Fesenmaier [3].

This study provides contributions that the role of community identification of COVID-19 activist community can bridge intrinsic motivation in the form of pleasure to help and hedonic value in the discipline of PSBB implementation. Likewise, community identification also mediates the extrinsic motivation in the form of reputation and reciprocity on the discipline of PSBB implementation.

\section{CONCLUSION}

This study found that intrinsic motivation which consists of pleasure to help and hedonic value has a negative significant influence on community identification of COVID-19 activist community. The extrinsic motivation, which consists of reputation and reciprocity has a negative significant influence on community identification of COVID19 activist community. Community identification mediates the influence between pleasure to help and hedonic value towards the discipline of the PSBB implementation. Community identification also mediates the influence between reputation and reciprocity on the discipline of the PSBB implementation.

\section{REFERENCES}

[1] Y. Wang, \& D.R. Fesenmaier, Assessing motivation of contribution in online communities: An empirical investigation of an online travel community. Electronic Markets, 13(1), 33-45, 2003.

[2] L. V. Casalo, \& M. Guinalíu, Determinants of the intention to participate in firm-hosted online travel communities and effects on consumer behavioral intentions. Tourism Management, 31(6), 898-911, 2010.

[3] Y. Wang, \& D.R. Fesenmaier, Towards understanding members' general participation in and active contribution to an online travel community. Tourism Management, 25(6), 709-722, 2004.

[4] S. J., Karau, \& K. D. Williams, Social loafing: A meta-analytic review and theoretical integration. Journal of Personality and Social Psychology, 65(4), 681-706, 1993.

[5] M.S.P. Hasibuan, Organisasi dan Motivasi:
Dasar Peningkatan Produktifitas, Bumi Aksara: Jakarta, 2006.

[6] L. Legault. Intrinsic and Extrinsic Motivation. Springer International Publishing, 2016.

[7] E. L. Deci, Effects of externally mediated rewards on intrinsic motivation. Journal of Personality and Social Psychology, 18, 105115, 1971.

[8] M. R. Lepper, D. Greene, \& R. E. Nisbett, Undermining children's intrinsic interest with extrinsic reward: A test of the "overjustification" hypothesis. Journal of Personality and Social Psychology, 28(1), 129-137, 1973.

[9] R. M., Ryan, \& E. L. Deci, Selfdetermination theory and the facilitation of intrinsic motivation, social development, and well-being. American Psychologist, 55 (1), 68-78, 2000.

[10] M., Osterloh, \& B. Frey. Motivation, knowledge, transfer, and organisational forms. Organization Science, 11(5), 538550, 2000.

[11] R. F. Baumeister, A self-presentational view of social phenomena. Psychological Bulletin, 91(1), 3-26, 1982.

[12] H. H., Chang, \& S. S. Chuang, Social capital and individual motivations on knowledge sharing: Partici, 2011.

[13] H. F. Lin, Effects of extrinsic and intrinsic motivation on employee knowledge sharing intentions. Journal of Information Science, 33(2), 135-149, 2007.

[14] Y. C., Shiue, C. M., Chiu, \& C. C. Chang, Exploring and mitigating social loafing in online communities. Computers in Human Behavior, 26(4), 768-77, 2010.

[15] L., Chidambaram, \& L. L. Tung, Is out of sight, out of mind? An empirical study of social loafing in technology-supported groups. Information Systems Research, 16(2), 149-168, 2008.

[16] Y. Chang. H.r.J. Ru-Jing, Kun Wangc.K., A. P., Cuid, \& C.B. Zhang. Effects of intrinsic and extrinsic motivation on social loafing in online travel communities.Computersin Human Behavior109 106360, 2020.

[17] K. H., Yoo, \& U. Gretzel, What motivates consumers to write online travel reviews? Information Technology \& Tourism, 10(4), 283-295, 2008.

[18] S. Y., Hung, A.Durcikova, H.M. Lai, \& W.M. Lin, The influence of intrinsic and extrinsic motivation on individuals' knowledge sharing behavior. International Journal of Human-Computer Studies, 69(6), 415-427, 2011. 